\title{
The Effect of Incorporating Ginger Extract (Zingiber officinale) to Cow Milk Kefir: An Analysis of Antioxidant and Microbiological and Physicochemical Characteristics
}

\author{
Putri Dian Wulansari*, Novia Rahayu and Nurul Frasiska \\ Agriculture Faculty, Universitas Perjuangan Tasikmalaya, Tasikmalaya, 46115 \\ *Corresponding author email: putridian@unper.ac.id
}

\begin{abstract}
Abstrak. This study aimed to analyze the antioxidant activities and microbiological and physicochemical characteristics of cow milk kefir fortified with ginger extract (Zingiber officinale). The ginger extract was incorporated together with grain before the fermentation. The levels of ginger extract concentrate were $0,0.5$, $1.0,1.5$, and $2.0 \%(\mathrm{w} / \mathrm{w})$. The ginger used in this study is a thick ginger extract that is added before the kefir fermentation process. The result showed that a higher level of ginger extract added to the fermentation could improve the antioxidant activities of the cow milk kefir. The kefir sample fortified with $2.0 \%$ ginger extract produced the highest antioxidant activities, particularly DPPH IC50 (0.32\%) and a total polyphenol of $0.72 \%$. This study found that the higher the ginger extract level, the lower the total count, total LAB, and total yeast. The average value of physicochemical characteristics for free fatty acid, lactic acids, alcohol, and $\mathrm{pH}$ in the present study was $0.5503 \mathrm{mg} / \mathrm{KOH}, 1.0005 \%, 1.628 \mathrm{~g} / \mathrm{dL}$, and 4.42, respectively. In conclusion, the ginger extract was effective for producing kefir with high antioxidant activities (DPPH IC50) and total polyphenol.
\end{abstract}

Keywords: antioxidant, ginger extract, kefir, functional food, cow milk

Abstrak. Penelitian ini bertujuan untuk menganalisis aktifitas antioksidan, karakteristik mikrobiologi dan fisikokimia kefir susu sapi yang diperkaya oleh ekstrak jahe (Zingiber officinale). Penambahan ekstrak jahe dilakukan bersamaan dengan penambahan grain sebelum proses fermentasi. Interval konsentrasi ekstrak jahe yang ditambahkan pada penelitian ini adalah: 0, 0.5, 1.0, 1.5, dan $2.0 \%(\mathrm{w} / \mathrm{w})$. Jahe yang digunakan pada penelitian ini merupakan ekstrak jahe kental yang ditambahkan sebelum proses fermentasi kefir. Hasil penelitian menunjukan bahwa peningkatan penambahan ekstrak jahe yang ditambahkan pada saat fermentasi mampu meningkatkan aktifitas antioksidan kefir susu sapi yang dihasilkan. Sampel Kefir yang diperkaya oleh $2.0 \%$ ekstrak jahe menunjukan aktifitas antioksidan paling tinggi dengan nilai aktifitas antioksidan DPPH IC ${ }_{50}$ sebesar $0.32 \%$ dan kadar polifenol total $0.72 \%$. Semakin tinggi penambahan ekstrak jahe semakin redah total count, total BAL dan total yeast yang dihasilkan. Rataan karakteristik fisiokokimia untuk asam lemak bebas, kadar asam laktat, kadar alkohol dan $\mathrm{pH}$ pada penelitian berturut-turut sebesar $0.5503 \mathrm{mg} / \mathrm{KOH}, 1.0005 \%$, $1.628 \mathrm{~g} / \mathrm{dL}$ dan 4.42. Kesimpulan pada penelitian ini adalah ekstrak jahe efektif digunakan untuk memproduksi kefir dengan aktifitas antioksidan DPPH IC ${ }_{50}$ dan kadar polifenol total yang tinggi.

Kata kunci: antioksidan, ekstrak jahe, kefir, makanan fungsional, susu sapi

\section{Introduction}

The natural sources of antioxidants are crucial to replace the synthesis antioxidants. Fermented milk is a proper antioxidant vehicle, and an additional microorganism during the fermentation process may improve antioxidant activities (Osuntoki and Korie, 2010). Accordingly, milk processing with fermentation technology could produce nutraceutical food due to antioxidant properties. Kefir is a potential fermented dairy product because it contains antioxidant activities. Previous studies reported that some kefir products, such as water kefir (Alsayadi et al., 2013), whey kefir (Osuntoki and Korie, 2010), cow milk kefir and soy milk kefir (Can et al., 2012; Kesenkas, 2011; Sirirat and Jelena, 2010) contain antioxidant properties.

Incorporating the isolation product from the antioxidant-loaded natural sources into kefir may improve its antioxidant activities. Ginger (Zingiber officinale) is a herbal plant that contains antioxidant activities, has been historically used as an alternative, traditional medication, and can be found extensively in Indonesia. Ginger is a good source of 
antioxidants, including polyphenol, flavonoid, and total tannin (PR and Prakash, 2010). Several efforts to incorporate ginger in other product of fermented milk (kefir) have been made and produced an impact on the physicochemical and sensory characteristics (Felfoul et al., 2017; Yang et al., 2012).

Based on the facts above, it is significant to evaluate the potential development of cow milk kefir fortified with ginger extract. To date, there have been limited references on the functional components of ginger extract for fermenting cow milk kefir, as well as their impacts on the antioxidant microbiology and physicochemical characteristics. This research aimed to investigate the effect of incorporating ginger extract to cow milk kefir on its antioxidant, microbiology and physicochemical characteristics.

\section{Materials and Methods}

\section{Research materials}

This research used fresh cow milk derived from the As-Salam Agrobusiness Farming Group in Tasikmalaya City; kefir grain from Milky Way, Bogor City; and white ginger/big yellow ginger from the traditional markets in Tasikmalaya Regency.

\section{Research methods}

The experimental research was conducted in a Completely Randomized Design (CRD) with five treatments and five replicates. The ginger extracts was added to kefir process at concentrations of $0 ; 0.5 ; 1.0 ; 1.5$ and $2 \% \mathrm{w} / \mathrm{w}$.

\section{The preparation of the ginger extract}

The ginger was washed under running water, drained well, sliced thinly, and sun-dried. The dried ginger was pulverized using a blender machine. The ginger extract preparation adopted method by Selawa et al. (2013). A total of $50 \mathrm{~g}$ ginger powder was macerated with $250 \mathrm{ml}$ pre-distilled ethanol in a $500-\mathrm{ml}$
Erlenmeyer for $24 \mathrm{~h}$, occasionally stirred, then the liquid was filtered to separate the filtrate and the pulp. The pulp was evaporated to obtain a thick extract.

\section{The preparation of Goat milk kefir}

The kefir making followed the existing method (Nurliyani et al., 2015) with a slight modification. The fresh cow milk was pasteurized $\left(72^{\circ} \mathrm{C} ; 15\right.$ seconds), incorporated with ginger extract according to the treatments, then inoculated with kefir grain $(10 \%)$ at room temperature, and incubated for $24 \mathrm{~h}$. The kefir yields were saved at $4^{\circ} \mathrm{C}$ to analyze the antioxidant, microbe, and physicochemical characteristics.

\section{The examination procedure}

The antioxidant activities were examined using a DPPH method (1,1- diphenyl-2picrylhydrazyl) (Molyneux, 2004) while the total polyphenol was calculated using folin reagent (Ghasemi et al., 2009). The total count, LAB, and yeast were determined by calculating the colonies and expressed in log CFU/ml using the Disk Diffusion method (Roostita et al., 2011). This procedure used Plate Count agar (PCA) (Merck) to determine the total count (Chen et al., 2006); deMan, Rogosa, and Sharpe Agar (MRS) (Merck) (Hwanhlem et al., 2011) to calculate total LAB, and Malt Extract Agar (MEA) (Oxoid) to count the total yeast (Ahmed, 2011). The antibacterial properties against Staphylococcus aureus ATCC 6538 and Escherichia coli ATCC 11229 was evaluated using a modified inhibition test (Singh et al., 1979). Furthermore, the analysis of free fatty acid was performed using $\mathrm{NaOH} 0,1 \mathrm{~N}$ (Sudarmadji et al., 1997), lactic acids using Mann's Acid Test (Sudarmadji et al., 1997), and alcohol using a distillation method (James, 1995). The $\mathrm{pH}$ value was measured using a $\mathrm{pH}$ Hanna calibrated at buffer $\mathrm{pH} 7$ and $\mathrm{pH} 4$. 


\section{Data Analysis}

The data were subjected to ANOVA (Steel and Torrie, 1996).

\section{Results and Discussion}

\section{Antioxidant Activities of Kefir}

The antioxidant activities of kefir samples fortified with ginger extract were analyzed by measuring two parameters, namely the antioxidant activities using the DPPH IC50 method and the total polyphenol. The obtained data showed that the higher the ginger extract, the higher the antioxidant activities in the cow milk kefir.

This research determined the antioxidant activities using 50\% DPPH IC50 as the inhibition value or $\mathrm{DPPH} /$ free radicals. The data of antioxidant activities in Table 1 show that it takes $26.62 \mathrm{~g} / \mathrm{ml}$ kefir without additional ginger extract to decrease the activity of DPPH IC50 free radicals. However, when $2 \%$ of ginger extract is incorporated in the kefir making, it only needs $1.32 \mathrm{~g} / \mathrm{ml}$ kefir to perform similarly. Therefore, $2.0 \%$ ginger extract could improve the antioxidant activity of cow milk kefir by $98.79 \%$ compared to control.

The data of total polyphenol are presented in Table 1. It illustrates that the total polyphenol of kefir with and without $2 \%$ ginger extract $0.72 \%$ and $0.16 \%$, respectively. The $2 \%$ ginger extract could improve the total polyphenol by $77.78 \%$ compared to the control.

The present study confirms Felfoul et al. (2017) that incorporating $1 \%(w / w)$ ginger powder could significantly improve the antioxidant activities and total polyphenol during storage (21 days, $40 \mathrm{C})$. The improvement is correlated with the high level of the bioactive peptide as a result of incorporating $1 \%(w / w)$ ginger powder. Furthermore, ginger powder affects the microbial metabolism of the phenolic compound that causes an increased production of phenolic acid (Felfoul et al., 2017). Accordingly, ginger extract incorporated into kefir making is efficient for producing antioxidant-enriched cow milk kefir.

\section{Microbiological Characteristics of Kefir}

The result of ginger extract added to cow milk kefir on the total count, $L A B$, and yeast is presented in Table 2. The Standard Codex for fermented milk (Codex Stan 243-2003) stated that the minimum total microorganism for the total count and the total $L A B$ was $10^{7}$, and the minimum total yeast was $10^{4}$. Treatment $0 \%$ ginger extract produced the total count and yeast that confirmed the standard, but the LAB was below the minimum codex standard. This study found that the more ginger extracts added to the kefir making, the lower the total count, LAB, and yeast. The decrease was due to the antibacterial activities contained in the ginger added to the kefir that inhibited bacteria activities in the kefir making (Sivasothy et al.2011).

This study produced higher total bacteria count than the total $L A B$ and yeast in the kefir because kefir contains not only $L A B$ but also acetic acids. Nurliyani et al. (2014) reported that kefir contained many species of bacteria, such as lactobacilli, lactococci, Leuconostoc (homofermantif and heterofermentif), acetic acid bacteria, Streptococcus thermophilus and yeast.

Table 1. Antioxidant characteristics of cow milk kefir fortified with ginger extract

\begin{tabular}{ccc}
\hline Treatment & Antioxidant activity $\left(\mathrm{DPPH} \mathrm{IC} \mathrm{C}_{50}\right)(\%)$ & Kadar Total polyphenol (\%) \\
\hline $0 \% \mathrm{GE}$ & 26.62 & 0.16 \\
$0.5 \% \mathrm{GE}$ & 1.75 & 0.27 \\
$1.0 \% \mathrm{GE}$ & 1.16 & 0.47 \\
$1.5 \% \mathrm{GE}$ & 0.34 & 0.7 \\
$2.0 \% \mathrm{GE}$ & 0.32 & 0.72 \\
\hline
\end{tabular}

Note: Treatment means the addition of ginger extract (GE) 
The average total count in the present study was $5.95-7.88 \log \mathrm{CFU} / \mathrm{ml}$, which was smaller than the previous studies, namely $8.89-9.91 \mathrm{log}$ $\mathrm{CFU} / \mathrm{ml}$ (Nurliyani et al., 2014) and $7.85-9.53$ log CFU/ml (HadiNezhad et al., 2013). The other research reported a total LAB of $4.3 \times 10^{8}$ $\mathrm{CFU} / \mathrm{ml}$ and total yeast of $6.6 \times 10^{5} \mathrm{CFU} / \mathrm{ml}$ (Jascolka et al., 2013).

Kéfir grain could grow in cow milk added with ginger extract during the fermentation. It confirms the previous studies by Yang et al. (2012) and Felfoul et al. (2017) that the LAB of kefir grain could grow well in the yoghurt making process incorporated with ginger extract. Therefore, the present study has successfully demonstrated that incorporating more ginger extract in the cow milk kefir has decreased the total count, $L A B$, and yeast. Additionally, despite these decreases, kefir grain could ferment cow milk added with ginger extract.

Data in Table 3 show that incorporating ginger extract did not affect the antibacterial properties of the cow milk kefir. The kefir yield in this study did not have antibacterial properties against Staphylococcus aureus ATCC 6538 and Escherichia coli ATC 11229 by using amoxicillin as the control. In contrast, Ulusoy et al. (2007) reported that the antibacterial properties in the kefir were produced by the commercial culture starter in a freeze-dried form (PROBATKC3, Danisco, Denmark) against Staphylococcus aureus (ATCC 29213), Bacillus cereus (ATCC 11778, Salmonella enteritidis (ATCC 13076), Listeria monocytogenes (ATCC 7644), and Escherichia coli (ATCC 8739) when compared to ampicillin and gentamicin. Another study stated that yoghurt and kefir exhibit antibacterial activities against Staphylococcus aureus ATCC 25922 and Escherichia coli ATC 25922 (Yesillik et al., 2011). The non-existing antibacterial properties in the cow milk kefir produced in this study could be due to the fermentation time and cold storage that significantly affected the antimicrobial activities (Ulusoy et al., 2007).

\section{Physicochemical Characteristics of Kefir}

Incorporating ginger extract in the kefir making did not affect $(P>0.05)$ its physicochemical characteristics that include free fatty acid, lactic acids, ethanol, and $\mathrm{pH}$ (Table 4). Additionally, the physicochemical characteristics reported in this study has achieved the standard quality of kefir product.

Table 2. Microbiological characteristics of cow milk kefir fortified with ginger extract

\begin{tabular}{cccc}
\hline Treatments & Total Count (CFU's/ml) & Total LAB (CFU's/ml) & Total Yeast (CFU's/ml) \\
\hline $0 \% \mathrm{GE}$ & $7.70 \times 10^{7}$ & $3.35 \times 10^{6}$ & $2.40 \times 10^{5}$ \\
$0.5 \% \mathrm{GE}$ & $3.35 \times 10^{7}$ & $1.93 \times 10^{6}$ & $0.31 \times 10^{5}$ \\
$1.0 \% \mathrm{GE}$ & $2.03 \times 10^{6}$ & $1.80 \times 10^{6}$ & $0.29 \times 10^{5}$ \\
$1.5 \% \mathrm{GE}$ & $1.08 \times 10^{6}$ & $1.35 \times 10^{6}$ & $0.19 \times 10^{5}$ \\
$2.0 \% \mathrm{GE}$ & $0.90 \times 10^{6}$ & $1.00 \times 10^{6}$ & $0.12 \times 10^{5}$ \\
\hline
\end{tabular}

Note: Treatment means the addition of ginger extract (GE)

Table 3. The antibacterial properties of cow milk kefir fortified with ginger extract

\begin{tabular}{ccc}
\hline Treatments & $\begin{array}{c}\text { Antibacterial against Staphylococcus } \\
\text { aureus ATCC 6538 }\end{array}$ & $\begin{array}{c}\text { Antibacterial against Escherichia coli } \\
\text { ATC 11229 }\end{array}$ \\
\hline $0 \% \mathrm{GE}$ & Inactive & Inactive \\
$0.5 \% \mathrm{GE}$ & Inactive & Inactive \\
$1.0 \% \mathrm{GE}$ & Inactive & Inactive \\
$1.5 \% \mathrm{GE}$ & Inactive & Inactive \\
$2.0 \% \mathrm{GE}$ & Inactive & Inactive \\
\hline
\end{tabular}

Note: Treatment means the addition of ginger extract (GE) 
Table 4. The physicochemical characteristics of cow milk kefir fortified with ginger extract

\begin{tabular}{ccccc}
\hline Treatments & Ethanol (\%) & $\begin{array}{c}\text { Free fatty acid } \\
(\mathrm{mg} / \mathrm{KOH})\end{array}$ & Lactic acids $(\%)$ & $\mathrm{pH}$ \\
\hline $0 \% \mathrm{GE}$ & $1.3132 \pm 0.107$ & $0.4211 \pm 0.068$ & $1.1009 \pm 0.015$ & $4.11 \pm 0.027$ \\
$0.5 \% \mathrm{GE}$ & $1.88 \mathrm{G} \pm 0.1307$ & $0.5417 \pm 0.041$ & $1.0107 \pm 0.011$ & $4.32 \pm 0$ \\
$1.0 \% \mathrm{GE}$ & $1.7667 \pm 0.139$ & $0.5261 \pm 0.042$ & $1.0270 \pm 0.007$ & $4.36 \pm 0.025$ \\
$1.5 \% \mathrm{GE}$ & $1.7514 \pm 0.126$ & $0.6227 \pm 0.049$ & $0.9098 \pm 0.007$ & $4.78 \pm 0.084$ \\
$2.0 \% \mathrm{GE}$ & $1.4218 \pm 0.1076$ & $0.6398 \pm 0.037$ & $0.9541 \pm 0.013$ & $4.58 \pm 0.029$ \\
\hline
\end{tabular}

Note: Treatment means the addition of ginger extract (GE)

Table 4 shows that incorporating ginger extract into cow milk kefir making did not affect the level of ethanol $(P>0.05)$ in the kefir, i.e., $1.0005 \%$ on average. The ethanol in kefir is the result of yeast activity against the glucose in milk. Yeast activity would produce alcohol in the fermented kefir (Sadiah et al., 2017). Furthermore, ginger extract added in the kefir making did not affect the level of alcohol.

Table 4 shows that the free fatty acid of cow milk kefir added with ginger extract was not significantly different across treatments $(P>0.05)$. The average free fatty acid in cow milk kefir added with ginger in this study was 0.5503 $\mathrm{mg} / \mathrm{KOH}$.

This study has shown that cow milk kefir incorporated with ginger extract $(0-2 \% \mathrm{w} / \mathrm{w})$ did not significantly affect the level of lactic acids $(P>0.05)$. It was in contrast with the previous study (Yang et al., 2012) that ginger juice affected the lactic acid yield because incorporating $10 \% \mathrm{v} / \mathrm{v}$ ginger could lower total $L A B$, thus decreasing the production of lactic acids. The level of lactic aids is the result of lactose degradation into simple sugar by lactic acid bacteria and yeast. This result reported that the lactic acid of cow milk kefir added with ginger extract was $1.628 \%$.

Incorporating ginger extract $(0-2 \% \mathrm{w} / \mathrm{w})$ in this study did not significantly affect the change of $\mathrm{pH}(\mathrm{P}>0.05)$. It was in contrast with the previous studies that reported significantly declined $\mathrm{pH}$ value of cow milk yoghurt due to the supplementation of $0-2.5 \% \mathrm{w} / \mathrm{w}$ ginger powder (Felfoul et al., 2017) and 2-10 \% v/v ginger juice (Yang et al., 2012). The average $\mathrm{pH}$ value in this study (4.43) was within the recommended range of $\mathrm{pH}$ for fermented milk products.

\section{Conclusions}

Incorporating $0-2.0 \% \mathrm{w} / \mathrm{w}$ ginger extract into cow milk for making kefir could decrease the growth of total count, $L A B$, and yeast. It improved the antioxidant activity but did not affect the physicochemical characteristics. Ginger extract was efficient to produce kefir with high antioxidant activities (DPPH IC50) and total polyphenol.

\section{Acknowledgement}

The authors express their gratitude to the Ministry of Research and Technology for the fund bestowed through the Competitive Grant and Junior Lecturer Research 2019.

\section{References}

Ahmed, I. A. M. 2011. Physicochemical, microbiological and sensory characteristics of yoghurt produced from camel milk during storage. Electronic Journal of Environmental, Agricultural and Food Chemistry (EJEAFChe), 10(6), 2305-2313.

Alsayadi, M., Al Jawfi, Y., Belarbi, M., and Sabri, F. Z. 2013. Antioxidant potency of water kefir. The Journal of Microbiology, Biotechnology and Food Sciences, 2(6), 2444-2447.

Can, E., Kurtoğlu, İ. Z., Benzer, F., Erişir, M., Kocabaş, M., Kızak, V., Çelik, H. T. 2012. The effects of different dosage of kefir with different durations on growth performances and antioxidant system in the blood and liver tissues of Çoruh trout (Salmo coruhensis). Turkish Journal of Fisheries and Aquatic Sciences, 12(2), 277-283. doi:10.4194/1303-2712-v12_2_12

Chen, M.-J., Liu, J., Sheu, J., Lin, C., and Chuang, C. 2006. Study on skin care properties of milk kefir 
whey. Asian-Australasian Journal of Animal Sciences, 19(6), 905-908.

Felfoul, I., Borchani, M., Samet-Bali, O., Attia, H., and Ayadi, M. 2017. Effect of ginger (Zingiber officinalis) addition on fermented bovine milk: rheological properties, sensory attributes and antioxidant potential. Journal of New Sciences, 44, 2400-2409.

Ghasemi, K., Ghasemi, Y. and Ebrahimzadeh, M. A. 2009. Antioxidant activity, phenol and flavonoid contents of 13 citrus species peels and tissues. Pak J Pharm Sci, 22(3), 277-281.

HadiNezhad, M., Duc, C., Han, N. F., and Hosseinian, F. 2013. Flaxseed soluble dietary fibre enhances lactic acid bacterial survival and growth in kefir and possesses high antioxidant capacity. Journal of Food Research, 2(5), 152. doi:10.5539/jfr.v2n5p152

Hwanhlem, N., Buradaleng, S., Wattanachant, S., Benjakul, S., Tani, A., and Maneerat, S. 2011. Isolation and screening of lactic acid bacteria from Thai traditional fermented fish (Plasom) and production of Plasom from selected strains. Food Control, 22(3-4), 401-407.

James, C. 1995. Analytical Chemistry of Food. Blackie academic and professional, an important of chapman and hall, university of Plymouth, London. Glasgow. New York. Tokyo. Melboune. Madras.

Jascolka, T., Aguilar, E., Teixeira, L., Lages, P., de Cássia Raimundo, I., Beltrão, N., Alvarez-Leite, J. 2013. Kefir Supplementation Improves lipid profile and oxidative stress but does not reduce atherosclerotic lesion in apoE deficient mice. J. Food Nutr. Disor, 2, 1-7.

Kesenkas, H. 2011. Antioxidant properties of kefir produced from different cow and soy milk mixtures. Journal of Agricultural Sciences, 17(3).

Molyneux, P. 2004. The use of the stable free radical diphenylpicrylhydrazyl (DPPH) for estimating antioxidant activity. Songklanakarin J. Sci. Technol, 26(2), 211-219.

Nurliyani, Harmayani, E., and Sunarti. 2014. Microbiological quality, fatty acid and amino acid profiles of kefir produced from combination of goat and soy milk. Pakistan Journal of Nutrition, 13(2), 107-115.

Nurliyani, Sadewa, A. H., and Sunarti. 2015. Kefir properties prepared with goat milk and black rice (Oryza sativa L.) extract and its influence on the improvement of pancreatic [beta]-cells in diabetic rats. Emirates Journal of Food and $\begin{array}{lll}\text { Agriculture, } & 27(10),\end{array}$ doi:10.9755/ejfa.2015.04.138

Osuntoki, A. and Korie, I. 2010. Antioxidant activity of whey from milk fermented with Lactobacillus species isolated from Nigerian fermented foods. Food Technology and Biotechnology, 48(4), 505511.

PR, S. A. and Prakash, J. 2010. Chemical composition and antioxidant properties of ginger root (Zingiber officinale). Journal of Medicinal Plants Research, 4(24), 2674-2679.

Roostita, L., Fleet, G., Wendry, S., Apon, Z. and Gemilang, L. 2011. Determination of yeasts antimicrobial activity in milk and meat products. Advance Journal of Food Science and Technology, 3(6), 442-445.

Sadiah, I., Nurlaelasari, A. and Handayani, M.N., 2017, March. Physicochemical Characteristics of Mung Bean Kefir with Variation Levels of Skim Milk and Fermentation Time. In IOP Conference Series: Materials Science and Engineering (Vol. 180, No. 1, p. 012288). IOP Publishing.

Selawa, W., Runtuwene, M. R. J. and Citraningtyas, G. 2013. Kandungan Flavonoid dan Kapasitas Antioksidan Total Ekstrak Etanol Daun Binahong [Anredera cordifolia (Ten) Steenis.]. J. IImiah Farmasi, 2(1), 18-22.

Singh, J., Khanna, A. and Chander, B. 1979. Antibacterial activity of yogurt starter in cow and buffalo milk. Journal of Food Protection, 42(8), 664-665.

Sirirat, D. and Jelena, P. 2010. Bacterial inhibition and antioxidant activity of kefir produced from Thai jasmine rice milk. Biotechnology, 9(3), 332337.

Sivasothy, Y., Chong, W. K., Hamid, A., Eldeen, I. M., Sulaiman, S. F. and Awang, K. 2011. Essential oils of Zingiber officinale var. rubrum Theilade and their antibacterial activities. Food chemistry, 124(2), 514-517.

Sudarmadji, S., Haryono, B. and Suhardi. 1997. Prosedur Analisis untuk Bahan Makanan dan Pertanian (4 ed.). Yogyakarta: Liberty.

Ulusoy, B. H., Çolak, H., Hampikyan, H. and Erkan, M. E. 2007. An in vitro study on the antibacterial effect of kefir against some food-borne pathogens. Türk Mikrobiyoloji Cemiyeti Dergisi, 37(2), 103-107.

Yang, G.-H., Guan, J.-J., Wang, J.-S., Yin, H.-C., Qiao, F.-D. and Jia, F. 2012. Physicochemical and sensory characterization of ginger-juice yogurt during fermentation. Food Science and Biotechnology, 21(6), 1541-1548. doi:10.1007/s10068-012-0205-z

Yesillik, S., Yildirim, N., Dikici, A., Yildiz, A. and Yesillik, S. 2011. Antibacterial effects of some fermented commercial and homemade dairy products and $0.9 \%$ lactic acid against selected foodborne pathogens. Asian J. Anim. Vet. Adv, 6, 189-195. 